\title{
Antilisterial Effect of Bacteriocin SH01, Obtained from Enterococcus faecium SH01, in Ground Beef
}

\author{
Min-Ju Kim, Miran Jung, and Wang June Kim* \\ Department of Food Science and Biotechnology, Dongguk University-Seoul, Seoul 100-715, Korea
}

\begin{abstract}
From the previous study, Enterococcus faecium SH01 was isolated from mukeunji, an over-ripened kimchi, and it produced bacteriocin SH01. Bacteriocin SH01 showed an inhibitory effect against Listeria monocytogenes ATCC 19111, a bacterial strain causing human listeriosis. Crude bacteriocin SH01 was purified by ammonium sulfate precipitation and its inhibitory activity at two concentrations (500 and 1,000 AU/g) against Listeria monocytogenes ATCC 19111 was investigated in ground beef at increasing temperatures $(5,10,15$, and $20^{\circ} \mathrm{C}$ ) for $8 \mathrm{~d}$. The number of Listeria monocytogenes ATCC 19111 significantly decreased $(p<0.05)$ as the concentration of bacteriocin increased from 500 to $1,000 \mathrm{AU} / \mathrm{g}$. Intrinsic crude protease activities in ground beef were examined and increased as the temperature increased. Experiments varying both the concentrations of added bacteriocin SH01 and temperature demonstrated a maximum inhibition (2.33 log reduction of bacteria) in samples containing $1,000 \mathrm{AU} / \mathrm{g}$ of bacteriocin $\mathrm{SH} 01$ incubated at $20^{\circ} \mathrm{C}$. When the crude bacteriocin SH01 solution $(1,280 \mathrm{AU} / \mathrm{mL})$ was incubated with crude protease solutions at different temperatures, its activity decreased by only half (640 AU/mL), as assessed in an agar well diffusion assay. The finding that the antilisterial activity of bacteriocin SH01 increased with temperature can be explained by the fact that higher temperatures increase bacterial membrane fluidity, thereby promoting the cellular penetration of bacteriocin SH01 into L. monocytogenes. Bacteriocin SH01 may be an excellent candidate as a biopreservative for controlling L. monocytogenes growth in ground beef.
\end{abstract}

Key words: antilisterial bacteriocin SH01, ground beef

Received November 24, 2014 / Revised February 12, 2015 / Accepted February 12, 2015

\section{Introduction}

Listeriosis is a severe foodborne infection caused by the consumption of foods that are contaminated by Listeria monocytogenes (Silva et al., 2009). Particularly, immunocompromised persons, such as pregnant women, newborn children, and the elderly are very susceptible to L. monocytogenes infection (Cho and Kim, 2001; Lee et al., 1993). The outbreaks of listeriosis have been traced to many foods, such as fresh meats, fermented foods, vegetables, and poultry (Cho et al., 2011b; Koseki and Isobe, 2005; Schlech ${ }^{3 r d}$ et al., 1983; Sommers et al., 2003). Because it is ubiquitous in nature, is relatively resistant to acid and salt, and has the ability to grow at refrigeration temperatures, the potential for post-processing contamination of foods with L. monocytogenes is high (Cho et al., 2011a; Nielsen et al., 1990; Swaminathan and Gerner-Smidt,

*Corresponding author: Wang June Kim, Department of Food Science and Biotechnology, Dongguk University-Seoul, Seoul 100-715, Korea. Tel: +82-2-2260-3373, Fax: +82-2-2260-3373, E-mail: wjkim@dongguk.edu
2007). Typically, ground beef is used for many foods, i.e., hamburger patty, and it can be easily contaminated by $L$. monocytogenes and support the growth of the pathogen, leading to serious listeriosis (Jang et al., 2007).

Currently, the procedures recommended for avoiding contamination of foods by L. monocytogenes are employing HACCP and using antimicrobial compounds, such as organic acids, fatty acids, herb essential oils, $\mathrm{NaCl}$, and chemical preservatives (Neito-Lozano et al., 2006; Pucci et al., 1988; Todd et al., 2011). However, the antilisterial effects of these compounds are not strong, and there is an aversion towards the use of chemical preservatives in food. Many studies have suggested that some bacteriocinproducing lactic acid bacteria or purified bacteriocins may be used as natural preservatives in various foods (Cleveland et al., 2001; Eckner, 1992; Kim, 1993). However, since bacteriocins are proteinaceous in nature, to be effective, they must maintain their antibacterial activity in foods where the intrinsic protease activity is high, such as ground beef. In previous studies, a bacteriocin-producing strain of bacteria, Enterococcus faecium SH01, was isolated from Mukeunji, an over-ripened kimchi, and the bac- 
teriocin SH01 was found to have antilisterial activity (Seo et al., 2014).

The objectives of this study were to examine the antilisterial effect of bacteriocin SH01 in ground beef at different storage temperatures, with the purpose of evaluating its potential uses as a biopreservative.

\section{Materials and Methods}

\section{Bacterial strains and culture conditions}

L. monocytogenes ATCC 19111, a strain causing human listeriosis, was grown in $10 \mathrm{~mL}$ brain heart infusion (BHI) broth (Oxoid, UK) for $24 \mathrm{~h}$ at $37^{\circ} \mathrm{C}$, with two consecutive transfers. The bacterial cells were obtained by centrifugation (1736R, LaboGene, Korea; $16,600 \mathrm{~g}$ for $15 \mathrm{~min}$ at $4^{\circ} \mathrm{C}$ ) and washed twice in $10 \mathrm{~mL}$ of sterile peptone water $(0.1 \%, w / v$; Difco, USA). After a second washing, the cell suspension was diluted with sterile $0.1 \%(\mathrm{w} / \mathrm{v})$ peptone water to a number of 5-6 Log CFU $/ \mathrm{mL}$.

Bacteriocin SH01-producing Enterococcus faecium SH01 were grown in $10 \mathrm{~mL}$ of MRS broth (Difco, USA) for $24 \mathrm{~h}$ at $37^{\circ} \mathrm{C}$, with two consecutive transfers.

\section{Preparation of crude bacteriocin}

E. faecium $\mathrm{SH} 01$ was inoculated $(2 \%, \mathrm{v} / \mathrm{v})$ into $800 \mathrm{~mL}$ of MRS broth and incubated at $37^{\circ} \mathrm{C}$ for $24 \mathrm{~h}$ until the bacteria reached the late exponential phase of growth. The cells were harvested by centrifugation $(16,600 \mathrm{~g}, 15$ $\min$ at $4^{\circ} \mathrm{C}$ ) and the cell-free supernatant was obtained by filtration through a $0.20 \mu \mathrm{m}$-pore size membrane filter (Sartorius, Germany). While stirring at $4^{\circ} \mathrm{C},\left(\mathrm{NH}_{4}\right)_{2} \mathrm{SO}_{4}$ (Samchun Pure Chemical Co., Ltd., Korea) was added to the filtrate to achieve $50 \%$ saturation. The saturated solution was centrifuged $\left(16,600 \mathrm{~g}, 15 \mathrm{~min}\right.$ at $\left.4^{\circ} \mathrm{C}\right)$ and the precipitate was recovered. The precipitate was reconstituted in distilled and deionized water $\left(\mathrm{ddH}_{2} \mathrm{O}\right)$ and dialyzed against $\mathrm{ddH}_{2} \mathrm{O}$ using a benzoylated-cellulose dialysis sac (MWCO of $1.2 \mathrm{kDa}$; Sigma, USA) for $24 \mathrm{~h}$ at $4^{\circ} \mathrm{C}$ (Moon et al., 2004).

\section{Estimation of bacteriocin titer}

The bactericidal activities of the bacteriocin for the following steps were assayed by the agar well diffusion method with certain modifications (Seo et al., 2014). L. monocytogenes ATCC 19111 indicator was grown in MRS broth until reaching its mid-exponential phase of growth. The approximate number of $L$. monocytogenes ATCC 19111 on the plate was $5 \times 10^{6} \mathrm{CFU}$. The bacteriocin titer, expressed as arbitrary units $(\mathrm{AU} / \mathrm{mL})$, is defined as the reciprocal of the highest dilution that showed a clear zone of inhibition around the well of the indicator lawn.

\section{Sample treatment}

The effect of bacteriocin SH01 on the growth of L. monocytogenes in ground beef at different concentrations and storage temperatures was studied. Fresh $(<24 \mathrm{~h})$ ground beef was purchased from a local supermarket and a $L$. monocytogenes suspension was inoculated to make initial levels of approximately 5-6 Log CFU/g. Crude bacteriocin solution $(1,280 \mathrm{AU} / \mathrm{mL})$ was added to the samples and mixed thoroughly in a stomacher bag to make final concentration of bacteriocin at $500 \mathrm{AU} / \mathrm{g}$ and 1,000 AU/g. Sterile water was used for the control. The samples were incubated at $5,10,15$, and $20^{\circ} \mathrm{C}$ for $8 \mathrm{~d}$.

\section{Microbiological analysis}

At day 8 , samples $(5 \mathrm{~g})$ were aseptically taken and mixed with $45 \mathrm{~mL}$ of sterile $0.1 \%(\mathrm{w} / \mathrm{v})$ peptone water and homogenized for $2 \mathrm{~min}$ in a stomacher (BagMixer 400, Interscience, France). Resulting slurries were serially diluted in $0.1 \%(\mathrm{w} / \mathrm{v})$ sterile peptone water, surface plated onto PALCAM Listeria Selective Agar (Oxoid, UK) with supplement (SR0150E, Oxoid, UK) (Solomakos et al., 2008) and incubated at $37^{\circ} \mathrm{C}$ for $48 \pm 24 \mathrm{~h}$. All the plating was repeated three times.

\section{Protease activity in ground beef}

In order to examine whether bacteriocin is destroyed by intrinsic proteolytic enzymes in ground beef during storage, total proteolytic activity was measured at different temperatures $\left(5,10,15\right.$, and $\left.20^{\circ} \mathrm{C}\right)$. At day $8,10 \mathrm{~g}$ of ground beef were taken from each sample and mixed with $100 \mathrm{~mL}$ of distilled water in flasks and incubated in a shaking incubator $(150 \mathrm{rpm})$ at $25^{\circ} \mathrm{C}$ for $4 \mathrm{~h}$. The meat exudates were centrifuged $(17,000 \mathrm{~g})$ at $4^{\circ} \mathrm{C}$ for $10 \mathrm{~min}$. The supernatants were filtered $(0.25 \mu \mathrm{m}$, Sartorius, Germany) and used as crude protease solutions. Three $\mathrm{mL}$ of $0.6 \%$ (w/v) casein solution (pH 7.0; C4765-10ML, Sigma, USA) was mixed with $1 \mathrm{~mL}$ of crude protease solution and incubated at $30^{\circ} \mathrm{C}$ for $10 \mathrm{~min}$. The reaction was stopped by the addition of $5 \mathrm{~mL}$ of $0.4 \mathrm{M}$ trichloroacetic acid (TCA; T4885-500G, Sigma, USA) at $30^{\circ} \mathrm{C}$ for $30 \mathrm{~min}$. The precipitate was filtered (Whatman No. 1, ADVANTEC, Japan) and $2 \mathrm{~mL}$ of the filtrate was neutralized with $5 \mathrm{~mL}$ of $0.4 \mathrm{M}$ sodium carbonate and incubated with 1 $\mathrm{mL}$ of $1 \mathrm{~N}$ Folin-Ciocalteu's reagent (Sigma, USA) at $30^{\circ} \mathrm{C}$ for $30 \mathrm{~min}$. The absorbance at $660 \mathrm{~nm}$ was measured using a spectrophotometer (Smart Plus SP-1900PC, 
Table 1. Antilisterial activity of bacteriocin SH01 in ground beef at different concentrations and temperatures at day 8

\begin{tabular}{|c|c|c|c|c|}
\hline \multirow{2}{*}{$\begin{array}{c}\text { Bacteriocin } \\
\text { concentration }\end{array}$} & \multirow{2}{*}{ Temperature $\left({ }^{\circ} \mathrm{C}\right)$} & \multicolumn{3}{|c|}{ Number of L. monocytogenes (Log CFU/mL) } \\
\hline & & Control $^{\mathrm{a}}$ & Bacteriocin $\mathrm{SH} 01^{\mathrm{b}}$ & $a-b^{2)}$ \\
\hline \multirow{4}{*}{$500 \mathrm{AU} / \mathrm{g}^{1)}$} & 5 & $6.34 \pm 0.07$ & $5.84 \pm 0.10$ & 0.5 \\
\hline & 10 & $6.31 \pm 0.23$ & $5.34 \pm 0.03$ & 0.97 \\
\hline & 15 & $6.21 \pm 0.10$ & $5.19 \pm 0.01$ & 1.02 \\
\hline & 20 & $5.94 \pm 0.07$ & $4.87 \pm 0.17$ & 1.07 \\
\hline \multirow{4}{*}{$1,000 \mathrm{AU} / \mathrm{g}$} & 5 & $5.24 \pm 0.04$ & $4.71 \pm 0.20$ & 0.53 \\
\hline & 10 & $5.66 \pm 0.23$ & $4.51 \pm 0.20$ & 1.15 \\
\hline & 15 & $5.16 \pm 0.18$ & $3.54 \pm 0.24$ & 1.62 \\
\hline & 20 & $4.31 \pm 0.44$ & $1.98 \pm 0.23$ & 2.33 \\
\hline
\end{tabular}

${ }^{1)} \mathrm{AU} / \mathrm{g}$ represents the reciprocal of the highest inhibitory dilution in the two-fold dilution assay.

${ }^{2)} \mathrm{Log}$ reduction of the number of L. monocytogenes ATCC 19111.

Woongki Science, Korea). Protease analyses were performed in triplicate. One unit of activity was defined as the amount of enzyme that liberated $1 \mu \mathrm{M}$ of tyrosine per $\mathrm{mL}$ of reaction mixture per min.

\section{Sensitivity/Endurance of bacteriocin in crude pro- tease solution}

The crude protease solution $(25 \mu \mathrm{L})$, obtained as described above, was mixed with $25 \mu \mathrm{L}$ of crude bacteriocin $(1,280 \mathrm{AU} / \mathrm{mL})$ and incubated at $5,10,15$, and $20^{\circ} \mathrm{C}$ for $1 \mathrm{~h}$. The residual bacteriocin titer was measured by a twofold dilution method using the agar well diffusion assay, as described above.

\section{Statistical analysis}

Microbiological and protease analyses were performed in triplicate. Data were subjected to analysis for significant differences between individual treatment groups using an SPSS 20 statistical package (SPSS Ltd., UK). Microbiological data and protease activity data were analyzed by ANOVA for identification of mean differences. A probability level of $p<0.05$ was used in determining the statistical significance of all experimental data.

\section{Results and Discussion}

\section{Antilisterial activity at different bacteriocin con- centrations and temperatures}

The initial numbers of L. monocytogenes found in all ground beef samples were not significantly different $(p>$ 0.05 ). Addition of bacteriocin $\mathrm{SH} 01$ at 500 and 1,000 AU/g significantly decreased $(p<0.05)$ the number of $L$. monocytogenes from the samples incubated at all temperatures examined. The antilisterial activity was higher in samples containing 1,000 AU/g bacteriocin compared to the $500 \mathrm{AU} / \mathrm{g}$ samples. Several researchers also found that the degree of inhibition of L. monocytogenes increased with increasing concentrations of nisin (500 to 1,000 IU/ g) and lactocin 705 (500 to 1,000 AU/g) (Pawar et al., 2000; Solomakos et al., 2008; Vignolo et al., 1996).

Antilisterial activity increased as the incubation temperature increased. Remarkably, a maximum 2.33 log reduction of L. monocytogenes was obtained from samples containing $1,000 \mathrm{AU} / \mathrm{g}$ bacteriocin incubated at $20^{\circ} \mathrm{C}$. Similar phenomena were reported by Abee et al. (1994) and Thomas and Wimpenny (1996) that the action of nisin against L. monocytogenes was drastically reduced at decreased temperatures. We haven't examined the fatty acid composition of indicator cell at different temperatures, but several researchers (Castellano et al., 2001; Mazzotta and Montville, 1997; Singh et al., 2001; Vignolo et al., 2000) also have reported that a change in membrane fatty acid composition (unsaturated versus saturated) and phospholipid content led to a decrease in membrane fluidity, as well as the inability of bacteriocin SH01 to penetrate more rigid membranes at lower temperatures.

\section{Protease versus bacteriocin activities at different temperatures}

The protease activities of samples gradually increased as the temperature increased (Table 2). The protease activity of the samples stored at refrigeration temperatures was rather low, while the protease activity of the samples stored at 15 and $20^{\circ} \mathrm{C}$ was relatively high. No significant differences $(p>0.05)$ in the samples stored at 5 and $10^{\circ} \mathrm{C}$ were found, while protease activity of the samples at 15 and $20^{\circ} \mathrm{C}$ were significantly higher $(p<0.05)$ compared to the samples stored at 5 and $10^{\circ} \mathrm{C}$.

Bacteriocin SH01 is a small peptide with a molecular weight of approximately $3 \mathrm{kDa}$ (Seo et. al., 2014). We predicted that it could be partially inactivated in the presence of intrinsic meat protease activity. After incubation 
Table 2. Intrinsic protease activity of ground beef at different temperatures at day 8

\begin{tabular}{cc}
\hline \hline Temperature $\left({ }^{\circ} \mathrm{C}\right)$ & Protease Activity $(\text { units } / \mathrm{mL})^{1)}$ \\
\hline 5 & $13.716 \pm 1.00$ \\
10 & $14.088 \pm 0.45$ \\
15 & $19.902 \pm 2.51$ \\
20 & $25.855 \pm 1.70$ \\
\hline
\end{tabular}

${ }^{1)}$ One unit of activity was defined as the amount of enzyme that liberated $1 \mu \mathrm{M}$ of tyrosine per $\mathrm{mL}$ of reaction mixture per min.

Table 3. Residual bacteriocin titer after protease treatment at different temperatures

\begin{tabular}{cc}
\hline \hline Temperature $\left({ }^{\circ} \mathrm{C}\right)$ & Bacteriocin titer $(\mathrm{AU} / \mathrm{mL})^{1)}$ \\
\hline 5 & 640 \\
10 & 640 \\
15 & 640 \\
20 & 640 \\
\hline
\end{tabular}

${ }^{1)}$ Crude protease solution was incubated with $1,280 \mathrm{AU} / \mathrm{mL}$ bacteriocin solution for $1 \mathrm{~h}$ at different temperatures and assayed by two-fold dilution against L. monocytogenes ATCC 19111 .

of bacteriocin SH01 with crude protease solution at different temperatures, the activities of all of the samples decreased by one half (Table 3). It appears that the antilisterial activity of bacteriocin SH01 was partially affected by intrinsic protease activity present in ground beef.

In conclusion, the antilisterial activity of bacteriocin SH01 increased in a dose-dependent manner. Intrinsic protease activity in ground beef increased as the temperature increased. Approximately $50 \%$ of the bacteriocin SH01 activity was lost by intrinsic protease activity. However, maximum antilisterial activity (2.33 log reduction) was obtained at $20^{\circ} \mathrm{C}$. The temperature abuse in a refrigerator can easily increase internal temperatures up to $20^{\circ} \mathrm{C}$, which could cause an outbreak of listeriosis. Based on these properties, bacteriocin $\mathrm{SH} 01$ can be used as an effective antilisterial food preservative in ground beef if it is safe for human consumption.

\section{References}

1. Abee, T., Rombouts, F. M., Hugenholtz, J., Guihard, G., and Letellier, L. (1994) Mode of action of nisin Z against Listeria monocytogenes Scott A grown at high and low temperatures. Appl. Environ. Microbiol. 60, 1962-1968.

2. Castellano, P., Farías, M. E., Holzapfel, W., and Vignolo, G. (2001) Sensitivity variations of Listeria strains to the bacteriocins, lactocin 705, enterocin CRL35 and nisin. Biotechnol. Lett. 23, 605-608.

3. Cho, J. I., Lee, S. H., Lim, J. S., Kwak, H. S., and Hwang, I. G. (2011a) Development of a predictive model describing the growth of Listeria monocytogenes in fresh cut vegetable. $J$.
Food Hyg. Safety 26, 25-30.

4. Cho, J. I., Lee, S. H., Lim, J. S., Kwak, H. S., and Hwang I. G. (2011b) Predictive mathematical model for the growth kinetics of Listeria monocytogenes on smoked salmon. $J$. Food Hyg. Safety 26, 120-124.

5. Cho, S. H. and Kim, Y. R. (2001) Antimicrobial effects of Scutellariae Radix extract against Listeria monocytogenes. $J$. Kor. Soc. Food. Sci. Nutr. 30, 959-963.

6. Cleveland, J., Montville, T. J., Nes, I. F., and Chikindas, M. L. (2001) Bacteriocins: Safe, natural antimicrobials for food preservation. Int. J. Food Microbiol. 71, 1-20.

7. Eckner, K. F. (1992) Bacteriocins and food application. Dairy Food Environ. Sanit. 12, 204-209.

8. Jang, J. S., Lee, H. J., Oh, B. Y., Lee, J. M., Go, J. M., and Kim, Y. H. (2007) Inactivation of Escherichia coli O157:H7, Salmonella and Listeria monocytogenes by organic acid. Kor. J. Env. Hlth. 33, 403-407.

9. Kim, W. J. (1993) Bacteriocins of lactic acid bacteria: Their potentials as food biopreservative. Food Rev. Int. 9, 293-313.

10. Koseki, S. and Isobe, S. (2005) Prediction of pathogen growth on iceberg lettuce under real temperature history during distribution from farm to table. Int. J. Food Microbiol. 104, 239248.

11. Lee, W. W., Kim, B. J., Lim, K. J., and Shin, J. B. (1993) Effects of preservatives on inhibition and survival of Listeria monocytogenes. Kor. J. Vet. Serv. 16, 20-33.

12. Mazzotta, A. S. and Montville, T. J. (1997) Nisin induces changes in membrane fatty acid composition of Listeria monocytogenes nisin-resistant strains at $10^{\circ} \mathrm{C}$ and $30^{\circ} \mathrm{C} . \mathrm{J}$. Appl. Microbiol. 82, 32-38.

13. Moon, G. S., Kang, C. H., Pyun, Y. R., and Kim, W. J. (2004) Isolation, identification, and characterization of a bacteriocinproducing Enterococcus sp. from Kimchi and its application to Kimchi fermentation. J. Microbiol. Biotechnol. 14, 924931.

14. Nielsen, J. W., Dickson, J. S., and Crouse, J. D. (1990) Use of a bacteriocin produced by Pediococcus acidilactici to inhibit Listeria monocytogenes associated with fresh meat. Appl. Environ. Microbiol. 56, 2142-2145.

15. Nieto-Lozano, J. C., Reguera-Useros, J. I., Pelaez-Martinez, M. D. C., and Hardisson de la Torre, A. (2006) Effect of a bacteriocin produced by Pediococcus acidilactici against Listeria monocytogenes and Clostridium perfringens on Spanish raw meat. Meat Sci. 72, 57-61.

16. Pawar, D. D., Malik, S. V. S., Bhilegaonkar, K. N., and Barbuddhe, S. B. (2000) Effect of nisin and its combination with sodium chloride on the survival of Listeria monocytogenes added to raw buffalo meat mince. Meat Sci. 56, 215-219.

17. Pucci, M. J., Vedamuthu, E. R., Kunka, B. S., and Vandenbergh, P. A. (1988) Inhibition of Listeria monocytogenes by using bacteriocin PA-1 produced by Pediococcus acidilactici PAC 1.0. Appl. Environ. Microbiol. 54, 2349-2353.

18. Schlech ${ }^{3 r d}$, W. F., Lavigne, P. M., Bortolussi, R. A., Allen, A. C., Haldane, E. V., Wort, A. J., Hightower, A. W., Johnson, S. E., King, S. H., Nicholls, E. S., and Broome, C. V. (1983) Epidemic listeriosis-evidence for transmission by food. N. Engl. 
J. Med. 308, 203-206.

19. Seo, S. H., Jung, M., and Kim, W. J. (2014) Antilisterial and amylase-sensitive bacteriocin producing Enterococcus faecium SH01 from Mukeunji, a Korean over-ripened Kimchi. Food Sci. Biotechnol. 23, 1177-1184.

20. Silva, J., Teixeira, P., Barbosa, J., Almeida, G., Santos, I., and Magalhaes, R. (2009) Listeriosis: is it a problem? N. Biotechnol. 25, S378.

21. Singh, B., Falahee, M. B., and Adams, M. R. (2001) Synergistic inhibition of Listeria monocytogenes by nisin and garlic extract. Food Microbiol. 18, 133-139.

22. Solomakos, N., Govaris, A., Koidis, P., and Botsoglou, N. (2008) The antimicrobial effect of thyme essential oil, nisin, and their combination against Listeria monocytogenes in minced beef during refrigerated storage. Food Microbiol. 25, 120-127.

23. Sommers, C., Fan, X., Niemira, B. A., and Sokorai, K. (2003) Radiation (gamma) resistance and postirradiation growth of Listeria monocytogenes suspended in beef bologna containing sodium diacetate and potassium lactate. J. Food Prot. 66,
2051-2056.

24. Swaminathan, B. and Gerner-Smidt, P. (2007) The epidemiology of human listeriosis. Microb. Infect. 9, 1236-1243.

25. Thomas, L. V. and Wimpenny, J. W. (1996) Investigation of the effect of combined variations in temperature, $\mathrm{pH}$, and $\mathrm{NaCl}$ concentration on nisin inhibition of Listeria monocytogenes and Staphylococcus aureus. Appl. Environ. Microbiol. 62, 2006-2012.

26. Todd, E. C. D. and Notermans, S. (2011) Surveillance of listeriosis and its causative pathogens, Listeria monocytogenes. Food Cont. 22, 1484-1490.

27. Vignolo, G., Fadda, S., De Kairuz, M. N., de Ruiz Holgado, A. P., and Oliver, G. (1996) Control of Listeria monocytogenes in ground beef by 'Lactocin 705', bacteriocin produced by Lactobacillus casei CRL 705. Int. J. Food Microbiol. 29, 397-402.

28. Vignolo, G., Palacios, J., Farias, M. E., Sesma, F., Schillinger, U., Holzapfel, W., and Oliver, G. (2000) Combined effect of bacteriocins on the survival of various Listeria species in broth and meat system. Curr. Microbiol. 41, 410-416. 